\title{
Proteolytic enzyme arbitrated antagonization of helminthiasis by Cinnamomum cappara leaf extract in Pheretima posthuma
}

\author{
Kayeen Vadakkan ${ }^{1 *}$, Meena K Cheruvathur ${ }^{2}$, Anu S Chulliparambil ${ }^{3}$, Famy Francis ${ }^{3}$ and Anu P Abimannue ${ }^{1}$
}

\begin{abstract}
Background: There have been several studies carried out to irradiate Helminthiasis however very little research have been carried out where in the enzymatic activity of plants are exploited to antagonize infections. Here we are analyzing the anthelmintic activity of Cinnamomum cappara leaf extract against Pheretima posthuma complimented by proteolytic action.

Results: The fresh leaves of Cinnamomum cappara was collected from local areas of Thrissur during December 2019. Plants were identified and authenticated by morphological and molecular characterization. The enzymatic action was analyzed by plotting Lineweaver-Burk plot which suggested that the extract possess the Km $185.77 \mu \mathrm{M}$ for casein as substrate and obeyed Michaelis-Menten kinetics with typical hyperbolic relation with enzyme and increasing concentration of substrate. The effect of extract upon study subject was in directly proportional with concentration of antagonist where higher activities were obtained in high concentrations. The anatomical and histological studies suggested that the activity of extract was due to the degradation of muscular bundle of subject that resulted in the leakage of ceolomic fluid.

Conclusions: Cinnamomum cappara leaf extract possessed high degree of protease intervened anthelmintic activity against Pheretima posthuma. As the study subject show immense morphological and physiological resemblance with all other helminthic parasites, this results shall be adopted to further clinical and pharmacological applications.
\end{abstract}

Keywords: Cinnamomum cappara, Lineweaver-Burk plot, Pheretima posthuma, Proteolytic action

\section{Introduction}

Helminthiasis has proclaimed itself as one among the most important parasite animal diseases in the planet as it affect more than a $25 \%$ of the total world's population and effect in significant disease and disability. The increasing amount of contaminated soil catalyses the transmission, and infections with Ascaris lumbricoides, Trichuris trichiura, and hookworm [1].Worldwide it

\footnotetext{
* Correspondence: kayeenvadakkan@gmail.com

${ }^{1}$ Department of Biotechnology, St. Mary's College, 680020 Thrissur, Kerala, India

Full list of author information is available at the end of the article
}

causes notable economic instability especially in developing countries.The lack of knowledge about proper and adequate management of such parasitic outbreak exacerbate the scenario [2].Helminths can be classified into two major phyla among which first one comprises of the nematodes which include the major intestinal worms those are soil-transmitted helminths and also filarial worms that could cause lymphatic filariasis, onchocerciasis etc. The second category comprises of platyhelminths that embraces the flukes and tapeworms and this group could cause schistosomes, and cysticercosis [3]. Conventionally the usage of chemical parasiticides are preferred 
to control Helminthiasis, however over usage of such agents could result in depreciation that in turn result in environment and living organisms, It could also give rise to drug resistant parasites [4].

The recognition of the antigenic complexity of parasites has slowdown the vaccine development in the past the growth in systems biology have brought some new velocity to the area, however lack in parallel advances in product and clinical development sciences and the potential for a candidate vaccine to advance into clinical trials remains low. This decelerate the preclinical development, and clinical development of vaccines [5]. The possibilities of employing plant metabolites for the treatment of Helminthiasis can replace the conventional chemical drug mediated treatment. It is assumed that the plant derived natural drugs will have more compatibility and less toxic effects when compared that with its chemical counterparts [6]. Even though there have been several plants have been reported for its successful anthelminthic activity, the activity responsible for the action remains mostly unknown.Current phase of anthelminthic drug development demands novel strategies to overcome existing obstacles encountered [7]. In this study we analyze the effect of proteolytic enzyme depended antagonization of Helminthiasis by Cinnamomum cappara leaf extract.

\section{Materials and Methods}

\section{Collection and identification of plant material}

The fresh leaves of Cinnamomum cappara was collected from local areas of Thrissur during December 2019. Plants were identified and authenticated by a botanist Dr. Sr. Meena K Cheruvathur, Assistant professor, Department of Botany, St. Mary's College, Thrissur, Kerala and kept in herbarium under voucher number SMCT $\mathrm{SR} / \mathrm{CC} / 2019$. Further the identity of the plant was confirmed by the employment of sequencing rbcL gene marker [8]. Amplification of marker gene was done by the employment of universal primer and resulting nucleotide was sequenced. Thus obtained nucleotide sequence was analyzed for its phylogenetic relationship using nucleotide blast available in NCBI (National Centre for Biotechnological Information) home page.

\section{Extraction of bioactive fraction by decoction method}

The plant material was dried in shade at ambient temperature, and made it in to powder by electrical blender. The powdered material was stored in tightly closed glass bottles for further use. The crude aqueous extract of Cinnamomum cappara leaves was prepared using the powdered plant material by mixing it with $250 \mathrm{~mL}$ of distilled water in a flask which was then boiled for 30 minutes. The mixture was boiled until the volume reduced to $50 \mathrm{ml}$. Thus obtained crude extract was cooled and later filtered using what man filter paper $1 \mathrm{~mm}$ and collected in a reagent bottle. [9].

\section{Analysis of proteolytic activity by Cinnamomum cappara leaf extract}

The quantitative determination of protease was carried as follows. The reaction mixture was made by the crude extract containing $50 \mu \mathrm{g}$ protein in it, $0.5 \mathrm{ml}$ of Tris$\mathrm{HCl}$ buffer $(50 \mathrm{mM}$; pH 7.2) and $0.5 \mathrm{ml}$ of casein $(2 \%$ $\mathrm{w} / \mathrm{v})$ dissolved in citrate phosphate buffer $(50 \mathrm{mM}$; pH 6.8). The mixture was left to react at $37{ }^{\circ} \mathrm{C}$ for $1 \mathrm{~h}$ and the reaction was arrested by adding $1 \mathrm{ml}$ of $10 \%(\mathrm{w} / \mathrm{v})$ ice - cold TCA. The unreacted casein substrate was cleared away by centrifugation at $5,000 \mathrm{rpm}$ for $10 \mathrm{~min}$, later an aliquot $(0.5 \mathrm{ml})$ of the supernatant was taken and $2.5 \mathrm{ml}$ of the reagent comprising $2.9 \% \mathrm{Na} 2 \mathrm{CO} 3$ and $0.3 \mathrm{~N} \mathrm{NaOH}$ was added and followed by the addition of $0.75 \mathrm{ml}$ of Folin Ciocalteu's phenol reagent. The samples were incubated at $37{ }^{\circ} \mathrm{C}$ for $20 \mathrm{~min}$ and the absorbance was taken at $650 \mathrm{~nm}$. A standard curve constructed with tyrosine was utilized to calculate the protease activity [10]. One unit of protease activity $(\mathrm{U} / \mathrm{ml})$ was defined as the amount of enzyme that liberates $1 \mu \mathrm{mol}$ of tyrosine equivalent per minute under the assay conditions. From the obtained value the specific activity $(\mathrm{U} / \mathrm{mg}$ ) was derived by dividing total activity by total protein content. The total protein content of the leaf extracts was determined by the method of Bradford, (1976) wherein BSA was used as standard to generate the calibration curve in Bradford assay The effect of increasing substrate concentration upon rate of reaction was studied in constant reaction conditions such as $\mathrm{pH} 8.0$ and $37{ }^{\circ} \mathrm{C}$ where in $20 \mathrm{mg} / \mathrm{ml}$ crude plant extract was added to solution. The concentration of substrate varied from 1 to $150 \mu \mathrm{M}$ in each mixture. A blank was used in each specific substrate concentrations without the enzyme. The Michaelis-Menten constant $(\mathrm{Km})$ value was derived from Lineweaver-Burk plot [11].

\section{Activity dependent purification of bioactive fraction}

Crude Aqueous extract from Cinnamomum cappara leaf possessing positive proteolytic activity was subjected for silica gel column chromatography (60-120 mesh) and the bioactive compounds were eluted by the employment of appropriate solvents of varying polarity. Eluted fractions were screened for its activity; finally, positive fraction was concentrated and the lead component was identified by the employment of gas chromatography (Agilent 6890 series) equipped with HP-5MS column mass spectrometer [12] operated at initial column temperature of $30{ }^{\circ} \mathrm{C}$ and heated up to $300{ }^{\circ} \mathrm{C}$ at $10{ }^{\circ} \mathrm{C}$ $15 \mathrm{~min}$. Chromatographic conditions were: flow of $1.0 \mathrm{ml} / \mathrm{min}$ of high purity helium as carrier gas in split 


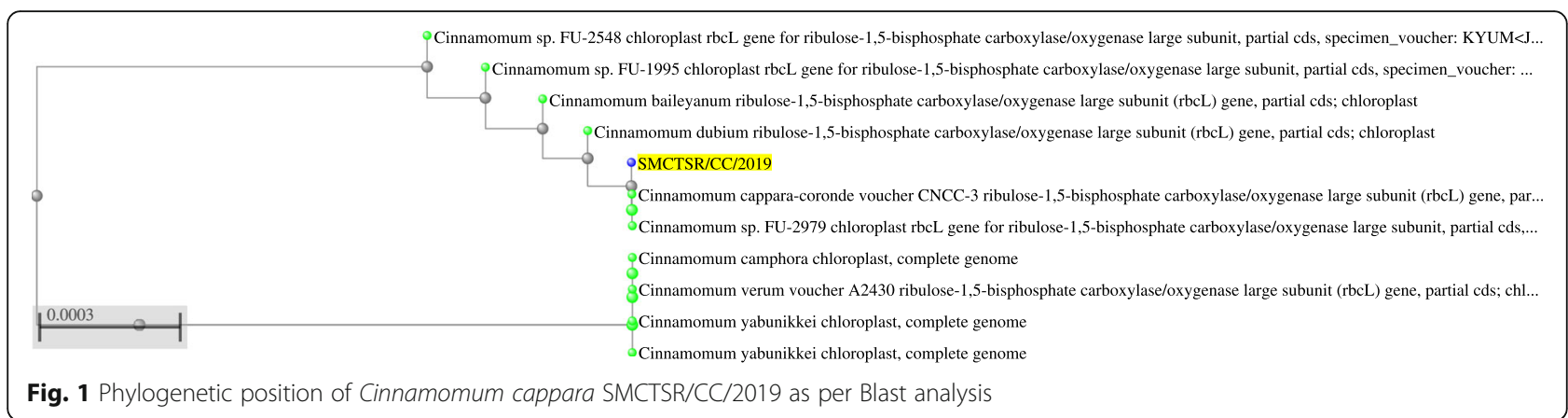

mode. The identification of the compounds in spectra was done based on retention time and integral area of peaks. The similarity of compounds matched based on NIST library search [13].

\section{Collection and maintenance of Pheretima posthuma}

All the experiments were carried out in Indian adult earthworms (Pheretima posthuma) due to its anatomical resemblance with the intestinal roundworm parasites of human beings. Pheritima posthuma with the average sze of 5-8 cm length was procured from Kerala Agricultural University, Vellanikkara, Thrissur, Kerala, India. The animals were maintained in moisture soil in the lab supplied with proper aeration [14].

\section{Experimental design for screening protease enzyme dependent anthelmintic activity}

The anthelmintic activity was performed according to the method. On adult Indian earth worm Pheretima posthuma as it has anatomical and physiological resemblance with the intestinal round worm parasites of humans. Pheretima posthuma was placed in petridish containing $25 \mathrm{ml}$ of test solution of varying concentrations of Cinnamomum cappara leaf extract ranging from 0 to $40 \mathrm{mg} / \mathrm{ml}$. Each Petri dish was placed with 6 worms and observed for paralysis or death. Mean time for paralysis was noted when no movement of any sort could be observed, except when the worm was shaken vigorously; the time death of worm (min) was recorded after ascertaining that worms neither moved when shaken nor when given external stimuli [15]. Albendazole $(50 \mathrm{mg} / \mathrm{ml})$ was used as the positive control while distilled water was considered as negative control. The observations obtained from the test was compared that with positive and negative control.

\section{Histological analysis of study subjects}

After the incubation period the treated samples were collected and washed with distilled water. After a depuration of $6 \mathrm{~h}$, as recommended by [16]. Earthworms were sequentially dehydrated in graded ethanol concentrations and embedded in paraffin wax with different melting points. Slides with cross sections of earthworms were stained using the hematoxylin-eosin method for light microscope observation, and photographed with an Labomed microscope equipped with a digital color camera Micaps pro HDMI [17].

\section{Statistical analysis}

The data obtained from the study was subjected to statistical analysis. The data was subjected to one-way ANOVA (Analysis of Variance) followed by Dunnett's post test using Graph-pad prism Version 5.01 software.

\section{Results}

Phylogenetic position of source plant SMCTSR/CC/2019 The plant isolate SMCTSR/CC/2019 that could successfully exhibit protease mediated anthelmintic activity was identified by the employment of sequencing rbcL marker gene. From the phylogenetic tree (Fig. 1) created from Blast results, It was evident that the plant is Cinnamomum cappara belongs to family Lauraceae and order Laurales. Subsequently the Blast results and phylogenetic analysis of rbcL gene sequence stated that the source plant Cinnamomum cappara isolate SMCTSR/ $\mathrm{CC} / 2019$ exhibited maximum similarity to

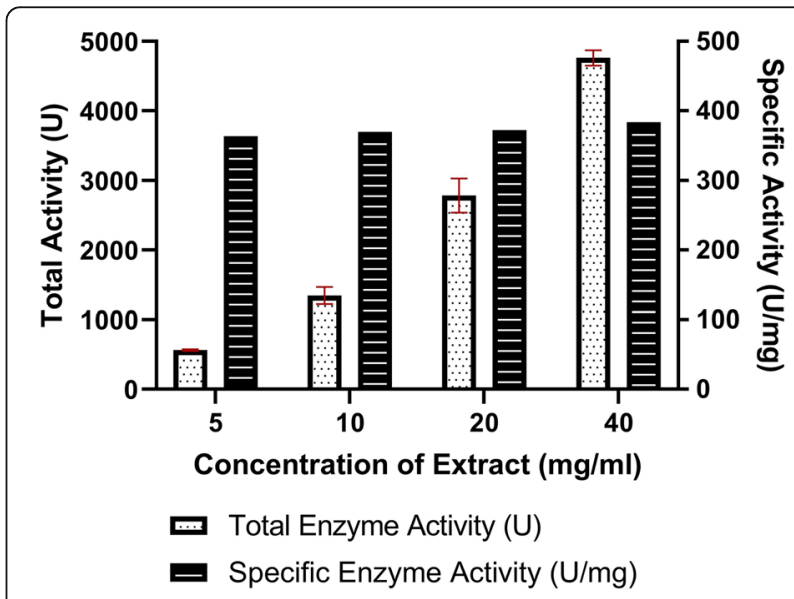

Fig. 2 Total enzyme activity and specific enzyme activity exhibited by Cinnamomum cappara leaf extract 
Table 1 Proteolytic activity of Cinnamomum cappara leaf extract

\begin{tabular}{lccc}
\hline Concentration of Extract $(\mathbf{m g} / \mathbf{m l})$ & Total Enzyme Activity $(\mathbf{U})$ & Total Protein $(\mathbf{m g} / \mathbf{m l})$ & Specific Enzyme Activity (U/mg) \\
\hline 5 & $565.33 \pm 13.57$ & $1.55 \pm 0.22$ & 363.94 \\
10 & $1345.66 \pm 124.27$ & $3.63 \pm 0.29$ & 370.02 \\
20 & $2784.66 \pm 246.17$ & $7.47 \pm 0.05$ & 372.61 \\
40 & $4763.66 \pm 109.86$ & $12.42 \pm 0.48$ & 383.44 \\
\hline
\end{tabular}

Cinnamomum cappara-coronde whose sequence was deposited in NCBI under the accession number of MK243400.1 and JN407386.1 respectively.

\section{Proteolytic activity and effect of substrate concentration} on the reaction velocity

Cinnamomum cappara leaf extract exhibited remarkable degree of Proteolytic activity where in the total enzymatic activity went up to $4763.66 \pm 109.86 \mathrm{U}$ in higher treated concentration that of $40 \mathrm{mg} / \mathrm{ml}$. The total enzymatic activity tends to be in correlation with that of concentration of plant extract wherein the Proteolytic action increased with increasing order of concentration (Fig. 2). It was interesting to understand that even though the total enzymatic activity was immensely influenced by the extract the specific enzyme action didn't possess much variation (Table 1). From the studies conducted in different substrate concentration it was understood that the enzyme followed Michaelis-Menten kinetics. There was a typical hyperbolic relation with enzyme and increasing concentration of substrate (Fig. 3) wherein the enzyme saturation was visible in higher substrate concentration. From the Lineweaver-Burk plot (Fig. 4) the $\mathrm{Km}$ was found to be $185.77 \mu \mathrm{M}$ for casein as substrate.

\section{Chemometric characteristics of bioactive fraction}

The bioactive fraction was subjected for gas chromatography and mass spectrometry subsequently to recognize

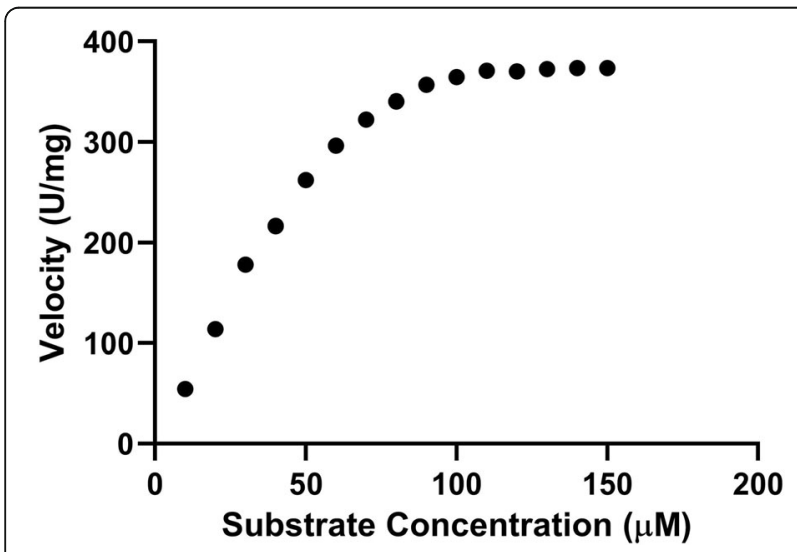

Fig. 3 Effect of substrate concentration on proteolytic activity upon casein as substrate the possible chemical composition of bioactive fractions. From the chromatogram obtained (Fig. 5) it was evident that the bioactive fraction of Cinnamomum cappara leaf extract comprises about seven major compounds and some trace components. Mass spectrometric analysis based on molecular mass suggested that the key component is Phenol, 3,5-di-tert-butyl (Fig. 6) which is an organic compound, with molecular formula $\mathrm{C}_{14} \mathrm{H}_{22} \mathrm{O}$ and molecular weight of $206.32 \mathrm{~g} / \mathrm{mol}$. This is colorless solid alkylated phenol and its derivatives are used industrially as UV stabilizers and antioxidants for hydrocarbonbased products. The peak was found in retention time 8.915.The identification was done by the employment of NIST library. Other Components those were found in the fraction was 9-Octadecenoic acid (Z)-, methyl ester which was present in retention time 15.402, 1Pentadecanol (CAS) Pentadecanol which presented itself in retention time of 15.226 . Other than these prominent compounds there were also some trace components in a negligible amount.

\section{Effect of Cinnamomum cappara leaf extract upon Pheretima posthuma}

The effect of Cinnamomum cappara leaf extract upon Pheretima posthuma suggested its potential anthelminthic property. The antagonizing activity was analyzed by subjecting Pheretima posthuma in varying concentrations (0 to $40 \mathrm{mg} / \mathrm{ml}$ ) of extract. It was observed that subjects exhibited diverse anatomical, morphological and behavioral changes in response to the treatment (Fig. 7). Escaping tendency was observed in all concentrations were in the higher concentration response was visible from 8th minute of administration wherein subjects remained peaceful in $5 \mathrm{mg} / \mathrm{ml}$ concentration up to 27th minute (Table 2). Non competence activity that of escaping moment accompanied by curling movement, wriggling movement etc. Higher degree of secretion of coelomic fluid was observed even in smaller concentrations. Subjects found to be getting paralyzed depending upon the concentration administrated. In higher concentration that of $40 \mathrm{mg} / \mathrm{ml}$ the paralysis was observed $21.66 \pm 2.08$ minutes after administration and found died at $25 \pm 1$ minute. In all the four different concentrations body elongation is the major morphological feature (Fig. 8). It was also evident that Cinnamomum cappara leaf extract could 


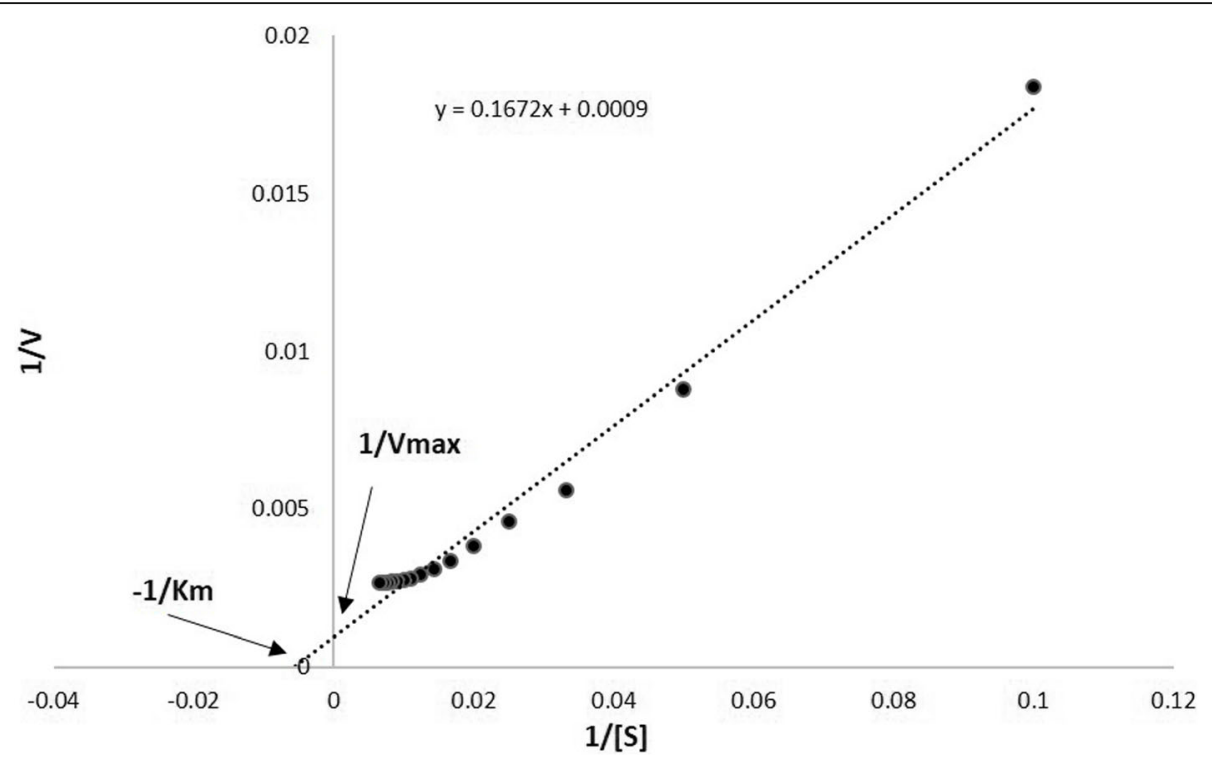

Fig. 4 Lineweaver-Burk plot indicating Michaelis-Menten constant (Km), Maximum velocity (Vmax) and Substrate concentration [S]

also affect the histological composition of Pheretima posthuma. Transverse sections of untreated earthworms indicated thick and intact epithelial layer, compact circular and longitudinal muscle layers, peritoneum and intestinal wall layers. Damaged cuticle and epithelial layers were found in the study animals in the presence of plant extract. Muscle layers were completely fused and vacuoles formed in between the longitudinal and circular muscles in this species. Thinning of epithelial layers was observed in clitellar region. Connective tissues were regularly degraded in that matter. Cellular debris was found in worms exposed to extract along with excessive mucilaginous secretion and slit degeneration of body wall layers (Fig. 9).

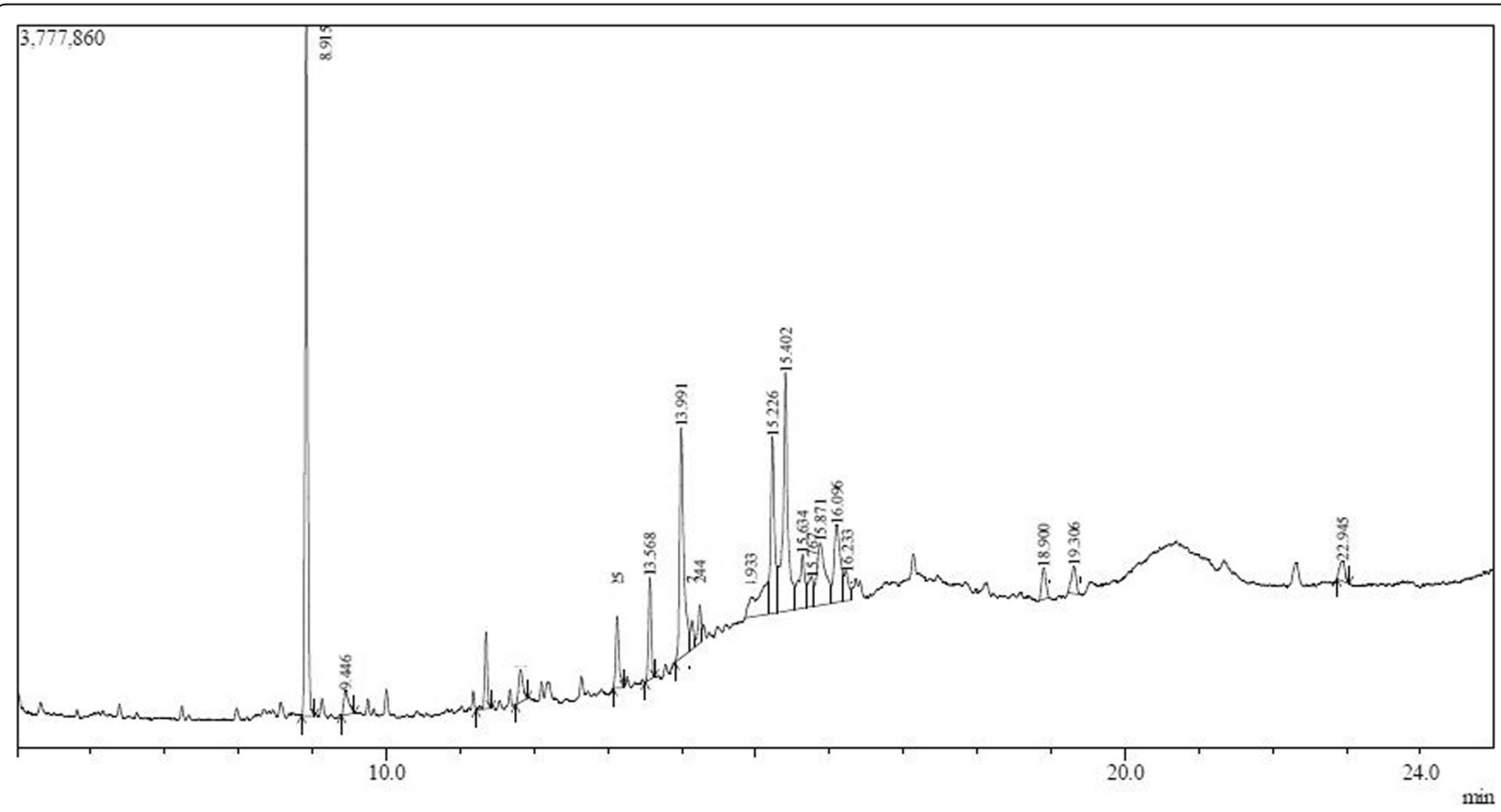

Fig. 5 Chromatogram of bioactive fraction extracted from Cinnamomum cappara leaf 


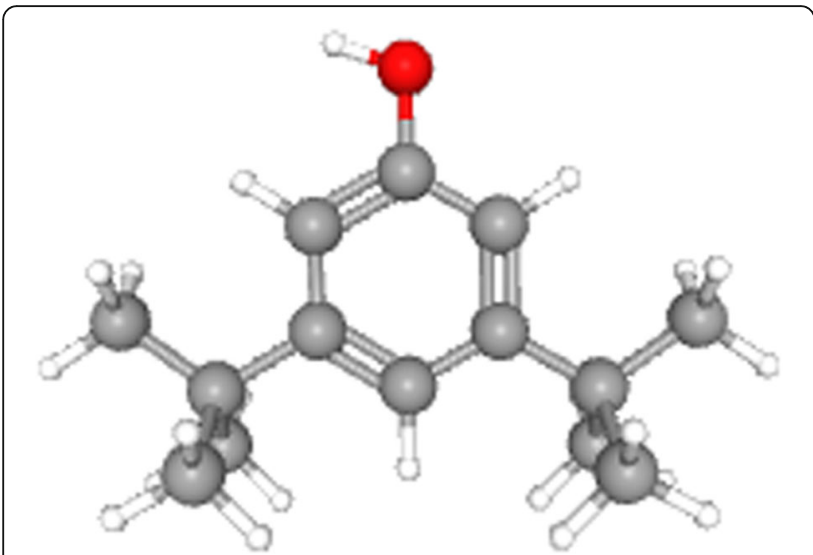

Fig. 6 3D representation of Phenol, 3,5-di-tert-butyl

\section{Discussion}

Cinnamomum (cinnamon) is a genus of the family Lauraceae, many of whose members are used as spices [18]. The genus comprises of small, evergreen trees and shrubs of about 10-15 $\mathrm{m}$ tall and are found in southeast Asia, China, and Australia as well as in Africa. The bark is widely used as spice, its leaves are ovate-oblong in shape, and exhibit a length of about 7-18 cm [19]. Flowers are arranged in panicles with a greenish color. The plant consists a purple colored fruit which is a $1 \mathrm{~cm}$ sized berry encompassing a single seed [20]. The genus Cinnamomum is considered to be highly medicinal and it has proven its properties such as free radicle scavenging, anticancer ablity, antimicrobial action, antihyperlipidemic etc. [21].

Due to the vast diversity and abundance of species range, marker based molecular identification is considered to be ideal for Cinnamomum Genus. Identification of plants by the employment of molecular markers give away the apprehension of errors that generally occur during identification based on morphological descriptions,
Table 2 Effect of extract in paralysis and death of Pheretima posthuma

\begin{tabular}{lcc}
\hline Concentration $(\mathbf{m g} / \mathbf{m l})$ & Paralysis $(\mathbf{m i n})$ & Death $(\mathbf{m i n})$ \\
\hline 5 & $55.66 \pm 2.08$ & $67 \pm 2$ \\
10 & $47.66 \pm 3.05$ & $50.66 \pm 1.52$ \\
20 & $32.66 \pm 1.15$ & $35.66 \pm 1.53$ \\
40 & $21.66 \pm 2.08$ & $25 \pm 1$ \\
\hline
\end{tabular}

therefore it is suggested to confirm the identity of plants by incorporating molecular markers as it offers high degree of species discrimination and fast results [22]. From the molecular sequencing we conducted we concluded that the plant belongs to Cinnamomum cappara. Similarly molecular characterization have been employed previously to confirm Cinnamomum verum Presl [23], trnL-trnF based identification of Cinnamomum spp [24] etc. We used rbcL (Ribulose bisphosphate carboxylase large chain) marker based identification as it is considered standard plant DNA barcoding markers due to their universality, relatively high overall sequence quality, low cost, and high discriminatory power between species $[8,25]$.

Proteolytic enzymes break the peptide bonds of proteins and they can be classified into acid, neutral, and alkaline proteases. Protease enzymes can be obtained from plants, animals, and microorganisms [26]. Our studies indicated that the plant extracts can be a virtuous proteolytic agents, similar suggestions have been previously made by Chinnadurai et al. (2018) where they studied the protease activity leaf extract of eighty medicinal plants. It is also perceived that the leaves of Moringa oleifera could successfully demonstrate peptide degrading activity [27]. From the studies we conducted it was evident that Cinnamomum cappara leaf extract possess itself with an immense ability of proteolytic action that can be exploited in pharmaceutics and industries. The total enzyme activity tends to increase directly

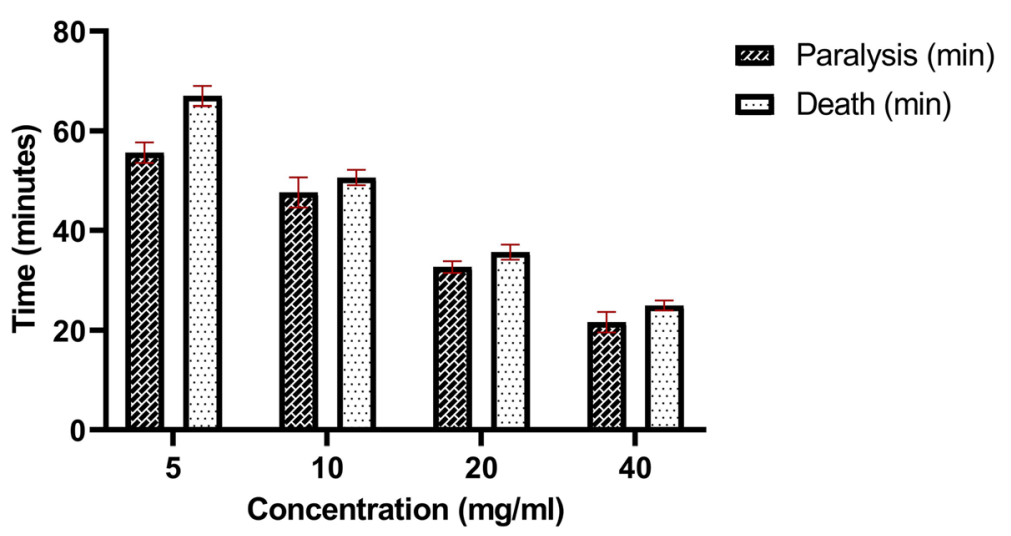

Fig. 7 Effect of CCLE upon death and paralysis of Pheretima posthuma 

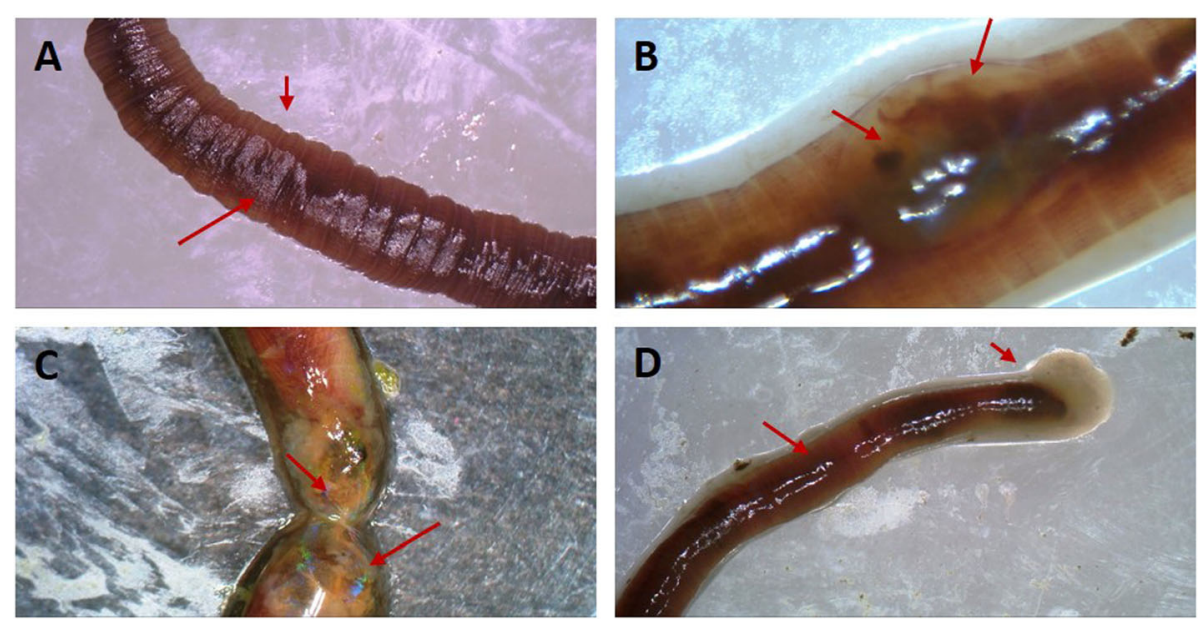

Fig. 8 Anatomical and morphological aberrations caused by extract on Pheretima posthuma. a: Normal Anatomy; b: Treated samples displaying muscular contraction; c: Treated samples showing coelomic fluid leakage; d: Treated samples showing high degree of endothermal ablation

proportional to the concentration, however the specific activity followed a standard range which could be due to the total protein content present in the extract as suggested by Feng et al., (2017) in their studies conducted by high-throughput estimation of specific activities of enzyme/mutants in cell lysates through immunoturbidimetric assay of proteins. It is also assumed that the antioxidant activities that is possessed by the extract might also have played a vital role in its anthelmintic activity [28]. The probable mechanism could be the activation of transcription factors that effect the natural physiological mechanism of subject [29].

Vast array of medicinal and industrial applications are displayed by phyto-proteases so far and some of them being the anti- Viral activity by the protease purified from Azadirachta indica and other medicinal plants [30], Cheese making ability by plant proteases extracted from Cynara scolymus L and Silybum marianum L. Gaertn [31]. However an important observation was made by Stepek et al., (2007) where they suggested that plant derived protease from kiwi fruit have remarkable Anthelmintic action against rodent stomach nematode, Protospirura muricola. This results were matching with the observations we made in our study where we observed protease enzyme mediated anthelminthic activity by Cinnamomum cappara leaf extract against Pheretima posthuma. The study organism resembles the similar physiological and anatomical structure with human
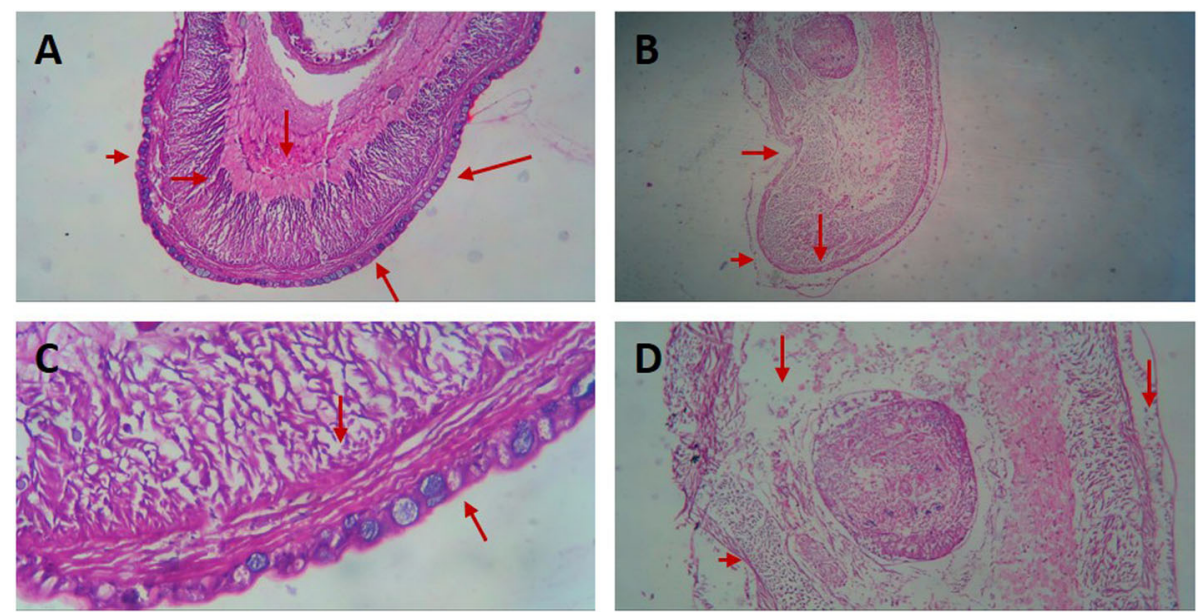

Fig. 9 Histological analysis of effect of extract upon Pheretima posthuma. a: Photomicrograph showing histology of normal subject (10x). b: Histology of treated subject (10x). c: Photomicrograph showing histology of normal subject (40 x), showing compactly arranged muscular bundle with proper connective tissues. $\mathbf{d}$ : Histology of treated subject (40x) indicating the muscular degradation 
intestinal parasites [32] therefore this observations shall be utilized against more parasites that cause Helminthiasis. Our studies suggested that proteolytic activity of plant extract could successfully cause degradation of muscle and hence death. Similarly various plant metabolites extracted from Picria fel-terrae Lour, Linariantha bicolor, Lansium domesticum have also reported their activity against Helminthiasis [33].

\section{Conclusions}

Cinnamomum cappara leaf extract possessed high degree of protease intervened anthelmintic activity against Pheretima posthuma. The histological and anatomical studies suggested that the activity of extract was due to the degradation of muscular bundle of subject that resulted in the leakage of ceolomic fluid. The analysis upon enzymatic kinetics obtained by plotting Lineweaver-Burk plot suggested that the extract possess the $\mathrm{Km}$ $185.77 \mu \mathrm{M}$ for casein as substrate and obeyed Michaelis-Menten kinetics with typical hyperbolic relation with enzyme and increasing concentration of substrate.

\section{Acknowledgements}

I would like to acknowledge Marian Centre for Advanced research, St. Mary's College Thrissur, Kerala, India for the infrastructure support and DST-FIST for providing facility to conducting research.

\section{Authors' contributions}

The research idea was conceived and initiated by Dr. Kayeen Vadakkan and the work was carried out by the combined effort of all authors. The author(s) read and approved the final manuscript.

\section{Funding}

This research did not receive any specific grant from funding agencies in the public, commercial, orNot-for-profit sectors.

\section{Availability of data and materials}

All the data and materials will be made available upon request.

\section{Ethics approval and consent to participate}

Not Applicable.

\section{Consent for publication}

We hereby declare our approval for publishing the article entitled "Proteolytic enzyme arbitrated antagonization of Helminthiasis by Cinnamomum cappara leaf extract in Pheretima posthuma" in Clinical Phytoscience.

\section{Competing interests}

We declare 'no competing interests'.

\section{Author details}

'Department of Biotechnology, St. Mary's College, 680020 Thrissur, Kerala, India. 'Department of Botany, St. Mary's College, 680020 Thrissur, Kerala, India. ${ }^{3}$ Marian Centre for Advanced Research, St. Mary's College, 680020 Thrissur, Kerala, India.

Received: 3 April 2020 Accepted: 9 February 2021

Published online: 18 February 2021

\section{References}

1. Jourdan PM, Lamberton PHL, Fenwick A, Addiss DG. Soil-transmitted helminth infections. Lancet [Internet]. Elsevier Ltd; 2018;391:252-65. Available from: https://doi.org/10.1016/S0140-6736(17)31930-X.
2. Akhtar MS, lqbal Z, Khan MN, Lateef M. Anthelmintic activity of medicinal plants with particular reference to their use in animals in the Indo-Pakistan subcontinent. Small Rumin Res. 2000;38:99-107.

3. Hotez PJ, Pearce EJ, Jacobson J, Hotez PJ, Brindley PJ, Bethony JM, et al. Helminth infections: the great neglected tropical diseases Find the latest version : Review series Helminth infections : the great neglected tropical diseases. J Clin Invest. 2008;118:1311-21.

4. Wang GX, Han J, Zhao LW, Jiang DX, Liu YT, Liu XL. Anthelmintic activity of steroidal saponins from Paris polyphylla. Phytomedicine [Internet]. Elsevier GmbH.; 2010;17:1102-5. Available from: https://doi.org/10.1016/j.phymed.2 010.04.012.

5. Diemert DJ, Bottazzi ME, Plieskatt J, Hotez PJ, Bethony JM. Lessons along the Critical Path: Developing Vaccines against Human Helminths. Trends Parasitol [Internet]. 2018;34:747-58. Available from: http://www. sciencedirect.com/science/article/pii/S1471492218301430.

6. Muthee JK, Gakuya DW, Mbaria JM, Kareru PG, Mulei CM, Njonge FK. Ethnobotanical study of anthelmintic and other medicinal plants traditionally used in Loitoktok district of Kenya. J Ethnopharmacol [Internet]. Elsevier Ireland Ltd; 2011;135:15-21. Available from: https://doi.org/10.1016/j. jep.2011.02.005

7. Zajíčková M, Nguyen LT, Skálová L, Raisová Stuchlíková L, Matoušková P. Anthelmintics in the future: current trends in the discovery and development of new drugs against gastrointestinal nematodes. Drug Discov Today [Internet]. 2020;25:430-7. Available from: http://www. sciencedirect.com/science/article/pii/S1359644619304660.

8. Moura CC, de M, Brambach, Bado F, Krutovsky KJH, Kreft KV, Tjitrosoedirdjo H. SS, et al. Integrating DNA barcoding and traditional taxonomy for the identification of dipterocarps in remnant lowland forests of sumatra. Plants. 2019;8.

9. Vadakkan K, Hemapriya J, Selvaraj V. Quorum quenching intervened in vivo attenuation and immunological clearance enhancement by Solanum torvum root extract against Pseudomonas aeruginosa instigated pneumonia in Sprague Dawley rats. Clin Phytoscience [Internet]. 2019;5:24. Available from: https://clinphytoscience.springeropen.com/articles/https://doi.org/1 0.1186/s40816-019-0120-4.

10. McDonald CE, Chen LL. The Lowry modification of the Folin reagent for determination of proteinase activity. Anal Biochem [Internet]. 1965;10:175-7. Available from: http://www.sciencedirect.com/science/article/pii/00032 69765902551.

11. Yadav SC, Pande M, Jagannadham MV. Highly stable glycosylated serine protease from the medicinal plant Euphorbia milii. Phytochemistry. 2006;67: 1414-26.

12. Dubey D, Patnaik R, Ghosh G, Padhy RN. InVitro Antibacterial Activity, Gas Chromatography-Mass Spectrometry Analysis of Woodfordia fruticosa Kurz. Leaf Extract and Host Toxicity Testing With InVitro Cultured Lymphocytes From Human Umbilical Cord Blood. Osong Public Heal Res Perspect [Internet]. Elsevier Korea LLC; 2014;5:298-312. Available from: https://doi. org/10.1016/j.phrp.2014.08.001.

13. Stein S. Mass Spectral Reference Libraries: An Ever-Expanding Resource for Chemical Identification. Anal Chem [Internet]. American Chemical Society; 2012;84:7274-82. Available from: https://doi.org/10.1021/ac301205z.

14. Rashid MMO, Ferdous J, Banik S, Islam MR, Uddin AHMM, Robel FN. Anthelmintic activity of silver-extract nanoparticles synthesized from the combination of silver nanoparticles and M. charantia fruit extract. BMC Complement Altern Med [Internet]. BMC Complementary and Alternative Medicine; 2016;16:1-6. Available from: https://doi.org/10.1186/s12906-016-1219-5.

15. Murugamani V, Raju L, Anand Raj VB, Sarma kataki M, Sankar GG. The New Method Developed for Evaluation of Anthelmintic Activity by Housefly Worms and Compared with Conventional Earthworm Method. ISRN Pharmacol [Internet]. 2012;2012:1-6. Available from: http://www.hindawi. com/journals/isrn/2012/709860/.

16. Darmawan ANDY, Raffiudin RIKA, Widarto TH. Morphological Characters and Histology of Pheretima darnleiensis. HAYATI J Biosci [Internet]. Institut Pertanian Bogor; 2012;19:44-8. Available from: https://doi.org/10.4308/hjb.1 9.1.44.

17. Morowati M. Histochemical and histopathological study of the intestine of the earthworm (Pheretima elongata) exposed to a field dose of the herbicide glyphosate. Environmentalist [Internet]. 2000;20:105-11. Available from: https://doi.org/10.1023/A:1006704009184.

18. Rao PV, Gan SH. Cinnamon: A multifaceted medicinal plant. Evidence-based Complement Altern Med. Hindawi Publishing Corporation; 2014;2014. 
19. Cardoso-Ugarte GA, López-Malo A, Sosa-Morales ME. Chapter 38 Cinnamon (Cinnamomum zeylanicum) Essential Oils. In: Preedy Flavor and Safety VRBT-EO in FP, editor. Med Spices Veg from Africa [Internet]. San Diego: Academic Press; 2016. p. 339-47. Available from: http://www. sciencedirect.com/science/article/pii/B9780124166417000389.

20. Mbaveng AT, Kuete V. Cinnamon Species. In: Kuete VBT-MS and V from A, editor. Med Spices Veg from Africa [Internet]. Academic Press; 2017. p. 38595. Available from: http://www.sciencedirect.com/science/article/pii/B978012 8092866000170

21. Ranasinghe P, Pigera S, Premakumara GS, Galappaththy P, Constantine GR, Katulanda P. Medicinal properties of "true" cinnamon (Cinnamomum zeylanicum): A systematic review. BMC Complement Altern Med [Internet]. BMC Complementary and Alternative Medicine; 2013;13:1. Available from: BMC Complementary and Alternative Medicine.

22. Sohn HB, Kim SJ, Hwang TY, Park HM, Lee YY, Markkandan K, et al. Barcode system for genetic identification of soybean [Glycine max (L.) Merrill] cultivars using indel markers specific to dense variation blocks. Front Plant Sci. 2017:8:1-12.

23. Abeysinghe PD, Wijesinghe, Kitulgala Gamaethige Gamini HT, Yoshda T. Molecular Characterization of Cinnamon (Cinnamomum verum Presl) Accessions and Evaluation of Genetic Relatedness of Cinnamon Species in Sri Lanka Based on TrnL Intron Region, Intergenic Spacers Between trnTtrnL, trnL-trnF, trnH -psbA and nuclear ITS. Res J Agric Biol Sci. 2012;50:46373.

24. Kojoma M, Kurihara K, Yamada K, Sekita S, Satake M, lida O. Genetic Identification of Cinnamon (Cinnamomum spp.) Based on the trnL-trnF Chloroplast DNA. Planta Med. 2002;68:94-6.

25. Fatima T, Srivastava A, Somashekar PV, Hanur VS, Rao MS. Development of DNA-based species identification and barcoding of three important timbers. Bull Natl Res Cent. Bulletin of the National Research Centre; 2019;43.

26. Flores-Gallegos AC, Delgado-García M, Ascacio-Valdés JA, Villareal-Morales $S$, Michel-Michel MR, Aguilar-González CN, et al Hydrolases of Halophilic Origin With Importance for the Food Industry. In: Kuddus MBT-E in FB, editor. Enzym Food Biotechnol Prod Appl Futur Prospect [Internet]. Academic Press; 2019. p. 197-219. Available from: http://www.sciencedirect.com/ science/article/pii/B978012813280700013X.

27. Banik S, Biswas S, Karmakar S. Extraction, purification, and activity of protease from the leaves of Moringa oleifera [version 1; peer review: 2 approved, 1 approved with reservations]. F1000Research. 2018;7.

28. Echeverría F, Ortiz M, Valenzuela R, Videla LA. Hydroxytyrosol and Cytoprotection: A Projection for Clinical Interventions. Int J Mol Sci [Internet]. MDPI; 2017;18:930. Available from: https://pubmed.ncbi.nlm.nih. gov/28452954.

29. Valenzuela R, Illesca P, Echeverría F, Espinosa A, Rincón-Cervera M, Ortiz M, et al. Molecular adaptations underlying the beneficial effects of hydroxytyrosol in the pathogenic alterations induced by a high-fat diet in mouse liver: PPAR- $\alpha$ and Nrf2 activation, and NF-KB down-regulation. Food Funct England. 2017:8:1526-37.

30. Gupta A, Shah A. Extraction of Proteases from Medicinal Plants and their Potential as Anti- Viral Targets. J Biotechnol Biomater. 2016;6.

31. Shah MA, Mir SA, Paray MA. Plant proteases as milk-clotting enzymes in cheesemaking: A review. Dairy Sci Technol. 2014;94:5-16.

32. Gogoi B, Kakoti BB, Bora NS, Yadav P. In vitro antihelmintic activity of bark extract of Cinnamomum bejolghota (Buch.-Ham.) in Indian adult earthworm (Pheretima posthuma). Asian Pacific J Trop Dis [Internet]. 2014;4:S924-7. Available from: http://www.sciencedirect.com/science/article/pii/S22221 80814607593.

33. Kumarasingha R, Preston S, Yeo TC, Lim DSL, Tu CL, Palombo EA, et al. Anthelmintic activity of selected ethno-medicinal plant extracts on parasitic stages of Haemonchus contortus. Parasites and Vectors [Internet]. Parasites \& Vectors; 2016;9:1-7. Available from: https://doi.org/10.1186/s13071-016-14 58-9.

\section{Publisher's Note}

Springer Nature remains neutral with regard to jurisdictional claims in published maps and institutional affiliations.

\section{Submit your manuscript to a SpringerOpen ${ }^{\circ}$ journal and benefit from:}

- Convenient online submission

- Rigorous peer review

- Open access: articles freely available online

- High visibility within the field

- Retaining the copyright to your article

Submit your next manuscript at $\boldsymbol{\nabla}$ springeropen.com 